\title{
Model Matriks Leslie dengan Strategi Pemanenan pada Kelompok Umur Termuda pada Angka Kesuburan dan Harapan Hidup Populasi Domba Betina
}

\author{
Dewi Anggreini \\ Program Studi Matematika; STKIP PGRI Tulungagung, Jl. Mayor Sujadi Timur No.7 Plosokandang, \\ Tulungagung, Jawa Timur Indonesia
}

Korespondensi; Email: anggreini_004@yahoo.com

\begin{abstract}
Abstrak
Penelitian ini bertujuan untuk Menentukan nilai eigen positif dan vektor eigen pada matriks Leslie dengan pemanenan pada kelompok umur termuda (Harvesting the youngest class) dan Mengetahui kebijaksanaan pemanenan dari masing-masing kelompok umur populasi domba betina saat pemanenan tiap tahun. Metode riset yang digunakan pada Tahap pertama adalah menentukan subjek penelitian dan Tahap Kedua adalah (1) mengumpulkan data penelitian (2) analisis data menggunakan apliaksi MAPLE dan terakhir menarik kesimpulan. Data penelitian ini diperoleh dari sekunder yaitu pertumbuhan populasi domba betina dalam periode 1 tahun yang populasinya dibagi menjadi 12 interval umur berdasarkan angka kesuburan dan harapan hidup. Parameter yang digunakan adalah nilai eigen dan vektor eigen matriks Leslie dengan pemanenan pada kelompok umur termuda. Hasil peneltian menunjukkan bahwa Nilai eigen positif pada matriks Leslie dengan pemanenan berdasarkan perhitungan aplikasi MAPLE adalah sebesar $\lambda_{1}=1,177$., Diperoleh Vektor eigen matriks Leslie dengan pemanenan pada kelompok umur termuda pada masing-masing interval umur. Kebijaksanaan pemanenan dari masing-masing kelompok umur populasi domba betina saat pemanenan tiap tahun adalah sebesar $17,9 \%$. Jadi, kebijaksanaan pemanenan kelompok umur yang termuda adalah sebesar $17,9 \%$ yaitu 179 ekor setiap tahun dari 1000 populasi domba betina.
\end{abstract}

Kata Kunci: Model pemanenan matriks Leslie; nilai eigen; vektor eigen; tingkat kesuburan; harapan hidup

\begin{abstract}
This study aims to determine the positive eigenvalues and eigenvectors of Leslie matrix by harvesting in the youngest age group (Harvesting the youngest class) and know the harvesting policy of each age group of sheep population at harvest each year. The research method used in the first phase is to determine the subject of research and Phase Two is (1) to collect research data (2) data analysis using MAPLE application and last draw conclusion. The data of this study were obtained from the secondary growth of female sheep population in a period of 1 year whose population was divided into 12 age intervals based on fertility rate and life expectancy. The parameters used were eigenvalues and eigenvectors of Leslie matrix with harvesting in the youngest age group. The result of the research shows that the positive eigenvalue of Leslie matrix by harvesting based on MAPLE application calculation is equal to $\lambda_{1}=1,177$, obtained by Leslie matrix eigenvector by harvesting in the youngest age group at each age interval. The harvesting policy of each age group of female sheep population at harvesting each year is $17.9 \%$. Thus, the policy of harvesting the youngest age group is $17.9 \%$ of 179 tails per year from 1000 female sheep populations.
\end{abstract}

Keywords: Leslie matrix model; eigen values; eigen vectors; fertility rate; life expectancy

\section{Pendahuluan}

Salah satu model yang digunakan oleh para ahli kependudukan untuk menjelaskan pertumbuhan populasi adalah model Leslie. Dimana model tersebut menggunakan pendekatan matematika yaitu matriks. Populasi betina merupakan populasi yang digunakan dalam perhitungan matriks Leslie. Faktorfaktor yang digunakan pada perhitungan dengan matriks Leslie adalah tingkat kesuburan, harapan hidup dan batas hidup populasi betina. 
Pemodelan matematika merupakan bidang matematika yang berusaha untuk merepresentasikan dan menjelaskan sistem-sistem fisik atau problem pada dunia real dalam pernyataan matematik, sehingga diperoleh pemahaman dari problem dunia real ini menjadi lebih tepat. Representasi matematika yang dihasilkan dari proses ini dikenal sebagai Model Matematika. Secara sederhana Candra (2012, hal.14) menjelaskan model matematika dapat didefinisikan sebagai suatu konstruksi matematis yang didesain untuk mempelajari suatu fenomena tertentu di dunia nyata.

Dalam penelitian ini matriks Leslie diaplikasikan dalam bidang peternakan yaitu untuk menghitung pemanenan populasi hewan yaitu populasi domba betina (Ovis aries betina). Pemanenan (Harvesting) dalam penelitian ini adalah tidak diartikan sebagai pemotongan hewan, tetapi pengambilan hewan dari populasi domba betina. Pemanenan populasi domba betina mengacu dengan yang disebut sebagai kebijaksanaan pemanenan yang dapat dibenarkan (sustainable harvesting policies). Kebijaksanaan pemanenan sangat penting dalam bidang peternakan populasi domba yaitu dapat memberikan keuntungan maksimum dan berkelanjutan (tidak terjadi kepunahan dari populasi domba betina yang dipanen).

Dalam penelitian ini strategi pemanenan yang digunakan adalah pemanenan pada kelompok umur termuda (Harvesting the youngest class) karena diterapkan pada populasi domba betina di suatu peternakan yang mudah dibedakan berdasarkan spesifikasi umur dalam menangkapnya. Sehingga hanya kelompok umur termuda saja yang akan diambil atau digunakan dalam setiap panen untuk menghindari kepunahan hewan. Domba dipelihara untuk diambil daging, susu dan bulunya. Dalam hal pembenihan, peternak lebih memilih domba yang masih muda daripada domba dewasa. Domba muda lebih murah dan mudah dalam perawatannya. Hal ini yang mendasari para peternak untuk mengambil sebagian dari populasi termuda untuk dipanen (dijual) sebagai benih.

Rumusan masalah pada penelitian ini adalah bagaimana menentukan nilai eigen positif dan vektor eigen pada matriks Leslie dengan pemanenan pada kelompok umur termuda serta bagaimana mengetahui kebijaksanaan pemanenan dari masing-masing kelompok umur populasi domba betina saat pemanenan tiap tahun. Adapun tujuan penelitian ini adalah pertama, menentukan nilai eigen positif pada matriks Leslie dengan pemanenan. Kedua, menentukan vektor eigen dari nilai eigen positif pada matriks Leslie dengan pemanenan pada kelompok umur termuda. Ketiga, mengetahui kebijaksanaan pemanenan dari masing-masing kelompok umur populasi domba betina saat pemanenan tiap tahun.

\section{Landasan Teori}

Terdapat beberapa penelitian tentang matriks Leslie yaitu penelitian Lestari (2009). Hasil penelitian adalah model populasi berdasar kelompok umur merupakan model untuk memprediksi jumlah populasi diwaktu yang akan datang berdasarkan kelompok umur. Penelitian Corazon, Nurul, H dan Yusienta, M (2016), diperoleh hasil jumlah populasi perempuan di Provinsi Riau cenderung mengalami peningkatan. Hasil penelitian Pratama, Prihandono dan Kusumastuti (2013) menggunakan matrik Leslie untuk mencari nilai eigen yang dominan dengan beberapa faktor yang berpengaruh dalam pertumbuhan populasi. Hasil penelitian Yuliani, Selvia, B.V, Rahayu, dan Mashuri (2012) yaitu untuk mendapatkan bibit ungggul pada tanaman dan hewan ternak, perlu dilakukan seleksi genetik, sifat-sifat yang diinginkan pada varietas unggul diseleksi dari beberapa generasi.

\footnotetext{
Matriks

Kariadinata (2013, hal.11) menjelaskan matriks adalah susunan sekelompok bilangan dalam suatu jajaran berbentuk persegi panjang yang diatur berdasarkan baris dan kolom, dan diletakkan diantara dua tanda kurung. Sedangkan menurut Anton (2004, hal.23) sebuah matriks dengan $n$ baris dan $n$ kolom dinamakan matriks kuadrat berorde $n$ (square matriks of orde $n$ ), dan entri-entri $a_{11}, a_{22}, \ldots, a_{n n}$ dikatakan berada pada diagonal utama dari $A$.
}

\section{Invers Matriks}

Menurut Kariadinata (2013, hal.115) jika $A$ adalah suatu matriks bujur sangkar (matriks kuadrat) dan kita dapat mencari matriks $B$ sehingga $A . B=B \cdot A=I$, maka A dikatakan dapat dibalik (invertible) dan $B$ dinamakan invers dari $A$. 


\section{Matriks Elementer}

Menurut Anton (2004, hal.56) suatu matriks $n \times n$ dinamakan matriks elementer (elementary matrix) jika matriks tersebut dapat diperoleh dari matriks satuan (identitas) $I_{n} n \times n$ dengan melakukan operasi baris elementer tunggal. Setiap matriks elementer dapat dibalik, dan inversnya juga merupakan matriks elementer.

\section{Determinan}

Menurut Kariadinata (2014, hal. 146) misalkan $A$ adalah matriks bujur sangkar. Fungsi determinan dinyatakan dengan det $\operatorname{dan} \operatorname{det}(A)$ didefinisikan sebaagai jumlah semua hasil kali dasar bertanda $A$. Angka $\operatorname{det}(A)$ disebut determinan $A$.

\section{Kombinasi Linear}

Definisi Anton (2004, hal.145) menyebutkan sebuah vektor $\boldsymbol{w}$ dinamakan kombinasi linear dari vektorvektor $\boldsymbol{v}_{\mathbf{1}}, \boldsymbol{v}_{\mathbf{2}}, \ldots, \boldsymbol{v}_{\boldsymbol{r}}$ jika vektor tersebut dapat diungkapkan dalam bentuk $\boldsymbol{w}=\boldsymbol{k}_{\mathbf{1}} \boldsymbol{v}_{\mathbf{1}}+$ $\boldsymbol{k}_{\mathbf{2}} \boldsymbol{v}_{\mathbf{2}}+\ldots+\boldsymbol{k}_{\boldsymbol{r}} \boldsymbol{v}_{\boldsymbol{r}}$, dengan $k_{1}, k_{2}, \ldots, k_{r}$ adalah skalar.

\section{Definisi 2.3 (Anton, 2004, hal.146)}

Jika $v_{1}, v_{2}, \ldots, v_{r}$ adalah vektor-vektor pada ruang vektor $V$ dan jika masing-masing vektor pada $V$ dapat dinyatakan sebagai kombinasi linear $\boldsymbol{v}_{\mathbf{1}}, \boldsymbol{v}_{\mathbf{2}}, \ldots, \boldsymbol{v}_{\boldsymbol{r}}$ maka dikatakan bahwa vektor-vektor ini merentang $V$.

\section{Kebebasan Linear \\ Definisi 2.4 (Anton, 2004, hal.249)}

Jika $S=\left\{\boldsymbol{v}_{\mathbf{1}}, \boldsymbol{v}_{\mathbf{2}}, \ldots, \boldsymbol{v}_{\boldsymbol{r}}\right\}$ adalah himpunan takkosong vektor-vektor, maka persamaan vektor $\boldsymbol{k}_{\mathbf{1}} \boldsymbol{v}_{\mathbf{1}}+$ $\boldsymbol{k}_{\mathbf{2}} \boldsymbol{v}_{\mathbf{2}}+\ldots+\boldsymbol{k}_{\boldsymbol{r}} \boldsymbol{v}_{\boldsymbol{r}}=0$ mempunyai paling sedikit satu solusi, yakni $k_{1}=0, k_{2}=0, \ldots, k_{r}=0$. Jika ini adalah satu-satunya solusi, maka $S$ dinamakan himpunan bebas linear (/inearly independent). Jika terdapat solusi-solusi lain, maka $S$ disebut sebagai himpunan tak bebas linear (linearly dependent).

\section{Nilai Eigen dan Vektor Eigen}

Menurut Kariadinata (2013, hal.209) jika $A$ adalah matriks berukuran $n \times n$, maka vektor tak nol $\mathbf{x}$ pada $R^{n}$ dinamakan vektor eigen (eigenvector) dari $A$ jika $A \mathbf{x}$ adalah kelipatan skalar dari x; yakni, $A \mathbf{x}=\lambda \mathbf{x}$ untuk skalar sebarang $\lambda$. Skalar $\lambda$ dinamakan nilai eigen (eigenvalue) dari $A$ dan $\mathbf{x}$ dikatakan vektor eigen yang bersesuaian dengan $\lambda$. Untuk mencari nilai eigen matriks $A$ yang berukuran $n \times n$ maka $A \mathbf{x}=\lambda \mathbf{x}$ dapat ditulis ulang sebagai $A \mathbf{x}=\lambda I \mathbf{x}$ atau ekuivalen dengan $(\lambda I-A) \mathrm{x}=0$. Agar $\lambda$ menjadi nilai eigen, harus ada solusi tak nol dari persamaan $(\lambda I-A) \mathrm{x}=0$, yang diperoleh jika dan hanya jika $\operatorname{det}(\lambda I-A)=0$.

\section{Bahan dan Metode}

\section{Rancangan Penelitian}

Pendekatan yang digunakan dalam penelitian ini adalah pendekatan kualitatif. Menurut Sugiyono (2017, hal.9) metode penelitian kualitatif adalah metode penelitian yang berlandaskan pada filsafat postpositivisme, digunakan untuk meneliti pada kondisi objek yang alamiah, dimana peneliti sebagai instrument kunci, teknik pengumpulan data dilakukan secara triangulasi (gabungan), analisis data bersifat induktif/kualitatif, dan hasil penelitian kualitatif lebih menekankan makna daripada generalisasi. Jenis penelitian ini termasuk penelitian Deskriptif. Sedangkan bentuk rancangan penelitian ini adalah Grounded Theory (teoretisasi data). Creswell (2017, hal.19) menyebutkan grounded theory merupakan rancangan penelitian yang didalamnya peneliti memperoleh teori umum dan abstrak dari suatu proses, aksi, atau interaksi, tertentu yang berasal dari pandangan-pandangan partisipan. Perlakuan yang akan diberikan terhadap data yaitu penerapan teori matrik Leslie dengan pemanenan pada kelompok umur termuda (harvesting the youngest class) pada populasi domba betina berbasis sistem aplikasi menggunakan MAPLE. 


\section{Sampel Sumber Data dan Sampling Penelitian}

Adapun sampel dalam penelitian ini adalah populasi domba peliharaan (Ovis aries betina) berdasarkan interval kesuburan dan harapan hidup. Dalam mengambil data penelitian menggunakan teknik purposive sampling. Moleong (2014, hal.224) menjelaskan pada penelitian kualitatif tidak ada sampel acak, tetapi sampel bertujuan (purposive sample) yang bertujuan untuk merinci kekhususan yang ada dalam ramuan konteks yang unik dan menggali informasi yang akan menjadi dasar dari rancangan dan teori yang muncul.

\section{Tahapan Penelitian}

Metode riset yang digunakan pada penelitian ini yaitu: Tahap pertama adalah menentukan subjek penelitian, adapun subjek penelitiannya adalah populasi domba peliharaan (Ovis aries betina) dan Tahap Kedua adalah (1) mengumpulkan data penelitian (2) analisis data dan terakhir menarik kesimpulan.

a) Tahap Persiapan

Menyusun metode penelitian meliputi: 1) Menentukan subjek penelitian (periode pertumbuhan populasi domba betina pada angka Kesuburan dan harapan hidup selama satu tahun) 2) Mengumpulkan data penelitian (data sekunder dari buku-buku, jurnal dan hasil penelitian yang relevan). 3) Analisis data dan terakhir menarik kesimpulan.

b) Teknik Pengumpulan Data

Data yang digunakan dalam penelitian adalah data sekunder. Data sekunder dikumpulkan dari berbagai sumber tertulis seperti buku-buku Aljabar Linear dan teori matriks beserta penerapannya, jurnal penelitian, dokumen-dokumen pendukung dan laporan penelitian yang relevan dengan penelitian ini.

c) Tahap Analisis dan Pelaporan

Langkah-langkah yang digunakan dalam menganalisis bentuk dan model penelitian ini adalah sebagai berikut: pertama, Pengecekan ulang data yang telah terkumpul (kelengkapan \&validitas data). Kedua, Data direduksi untuk dipilah yang akan dijadikan fokus analisis. Ketiga, Melakukan analisis data dengan mensubstitusikan nilai ai dan bi untuk membentuk matriks Leslie. Keempat, Data yang telah terkumpul di-entry (input process) ke dalam komputer. Kelima, menyusun laporan penelitian dan olahan data melalui aplikasi MAPLE 16.

\section{Rencana Pengujian Keabsahan Data}

Dalam penelitian ini pengujian kredibilitas data menggunakan peningkatan ketekunan. Ketekunan pengamatan bermaksud menemukan ciri-ciri dan unsur-unsur dalam situasi yang sangat relevan dengan persoalan atau isu yang sedang dicari dan kemudian memusatkan diri pada hal-hal tersebut secara rinci. Meningkatkan ketekunan dalam penelitian ini adalah dengan cara membaca referensi buku yang berkaitan dengan matriks dan buku pemodelan matematika. Jurnal-jurnal yang berkaitan dengan matriks leslie yang relevan serta dokumentasi-dokumentasi yang terkait dengan temuan yang diteliti.

\section{Teknik Analisis Data}

Teknik analisis data dalam penelitian ini yaitu pertama, Mensubtitusikan nilai ai (tingkat kesuburan populasi domba betina) dan $b_{i}$ (angka harapan hidup populasi domba betina) kedalam model matriks Leslie. Kedua, mencari nilai eigen $\lambda_{1}$ yang positif pada model matriks Leslie. Menentukan vektor eigen $x_{1}$ dari nilai eigen yang positif. Ketiga, Menentukan banyaknya bagian pemanenan populasi domba betina dengan rumus $h=1-\left(\frac{1}{\lambda_{1}}\right)$. Selanjutnya, diketahui banyaknya populasi domba betina betina untuk jangka waktu yang akan datang dan vektor distribusi umur populasi setelah pemanenan.

\section{Hasil dan Pembahasan}

Pada bagian ini akan dijelaskan terlebih dahulu mengenai pertumbuhan populasi menurut kelompok umur. 


\section{Model Matriks Leslie Dalam Pertumbuhan Populasi}

Dalam model Leslie, betina atau betina dibagi atas kelompok umur yang kurun waktunya sama. Secara spesifik, misalkan umur maksimum yang dicapai oleh sebarang betina atau betina didalam populasi itu adalah $M$ tahun (atau dinyatakan dalam satuan waktu yang lain) dan kemudian populasi itu dibagi atas $n$ kelompok umur. Maka kurun waktu dalam setiap kelompok $M / n$ tahun.

Misalnya diketahui banyaknya betina dalam setiap kelompok dari ke- $n$ kelompok tersebut pada waktu $t=0$. Khususnya, misalkan, ada $x_{1}{ }^{(0)}$ betina dalam kelompok pertama, $x_{2}{ }^{(0)}$ betina didalam kelopok kedua, $x_{3}{ }^{(0)}$ betina di dalam kelompok ketiga, dan seterusnya. Dengan bilangan ke- $n$ ini akan dibentuk sebuah vektor kolom $\mathbf{x}^{(0)}$ yaitu:

$$
\mathbf{x}^{(0)}=\left[\begin{array}{c}
x_{1}{ }^{(0)} \\
x_{2}{ }^{(0)} \\
\vdots \\
x_{n}{ }^{(0)}
\end{array}\right]
$$

vektor ini dinamakan vektor distribusi umur mula-mula (initial age distribution vektor).

\section{Parameter Dalam Model Matriks Leslie}

Proses kelahiran dan proses kematian diantara dua waktu pengamatan yang berturutan dapat dijelaskan dengan menggunakan parameter-parameter demografis berikut:

Tabel 1. Parameter dalam model Matriks Leslie.

\begin{tabular}{cl}
\hline $\begin{array}{c}a_{i} \\
i=1,2, \ldots, n\end{array}$ & $\begin{array}{l}\text { Jumlah rata-rata dari anak perempuan yang dilahirkan oleh seorang betina selama } \\
\text { dia berada dalam kelompok umur ke- } i .\end{array}$ \\
$b_{i}$ & $\begin{array}{l}\text { Banyaknya betina dalam kelompok umur ke- } i \text { yang dapat diharapkan masih hidup } \\
\text { dan sampai ke kelompok umur ke- }(i+1) .\end{array}$ \\
\hline
\end{tabular}

Berdasarkan definisinya, maka akan diperoleh bahwa (i) $a_{i} \geq 0$ untuk $i=1,2, \ldots, n$ dan (ii) $0<b_{i}$. Setiap kelompok umur di mana nilai $a_{i}$ yang bersangkutan adalah positif dinamakan kelompok umur subur (fertile age class). Selanjutnya akan didefinisikan vektor distribusi umur $\mathbf{x}^{(k)}$ pada waktu $t_{k}$ dengan

$$
\mathbf{x}^{(k)}=\left[\begin{array}{c}
x_{1}{ }^{(k)} \\
x_{2}{ }^{(k)} \\
\vdots \\
x_{n}{ }^{(k)}
\end{array}\right]
$$

di mana $x_{1}{ }^{(k)}$ adalah banyaknya betina atau betina dalam kelompok umur ke- $i$ pada waktu $t_{k}$. Pada waktu $t_{k}$, betina-betina dalam kelompok umur pertama adalah puteri dari betina-betina yang lahir diantara waktu $t_{k-1}$ dan waktu $t_{k}$. Secara matematis ditulis

$$
x_{1}{ }^{(k)}=a_{1} x_{1}{ }^{(k-1)}+a_{2} x_{2}{ }^{(k-1)}+\cdots+a_{n} x_{n}{ }^{(k-1)}
$$

Banyaknya betina dalam kelompok umur ke- $(i+1)(i=1,2, \ldots, n-1)$ pada waktu $t_{k}$ adalah betina dalam kelompok ke- $i$ pada waktu $t_{k-1}$ yang masih hidup pada waktu $t_{k}$. secara matematis,

$$
x_{i+1}^{(k)}=b_{i} x_{i}^{(k-1)}, i=1,2, \ldots, n-1
$$


Dengan menggunakan notasi matriks, persamaan (1) dan (2) dapat dituliskan dalam bentuk

Secara lebih ringkas

$$
\left[\begin{array}{c}
x_{1}^{(k)} \\
x_{2}^{(k)} \\
x_{3}^{(k)} \\
\vdots \\
x_{n}^{(k)}
\end{array}\right]=\left[\begin{array}{cccccc}
a_{1} & a_{2} & a_{3} & \cdots & a_{n-1} & a_{n} \\
b_{1} & 0 & 0 & \cdots & 0 & 0 \\
0 & b_{2} & 0 & \cdots & 0 & 0 \\
\vdots & \vdots & \vdots & & \vdots & \vdots \\
0 & 0 & 0 & \cdots & b_{n-1} & 0
\end{array}\right]\left[\begin{array}{c}
x_{1}^{(k-1)} \\
x_{2}^{(k-1)} \\
x_{3}^{(k-1)} \\
\vdots \\
x_{n}^{(k-1)}
\end{array}\right]
$$

$$
\mathbf{x}^{(k)}=L \mathbf{x}^{(k-1)}, \text { dengan } k=1,2, \ldots
$$

Di mana $L$ adalah matriks Leslie.

Akan diberikan teorema-teorema yang berkaitan dengan matriks Leslie, sebagai berikut:

Teorema 1. Sebuah matriks Leslie $L$ mempunyai sebuah nilai eigen positif yang unik $\lambda_{1}$. Nilai eigen ini mempunyai multiplisitas 1 dan mempunyai sebuah vektor eigen $\mathbf{x}_{1}$ yang semua entrinya adalah positif.

Teorema 2. Jika $\lambda_{1}$ adalah nilai eigen positif yang unik dari sebuah matriks Leslie $L$ dan jika $\lambda_{i}$ adalah sebarang nilai eigen riil atau kompleks dari $L$, maka $\left|\lambda_{k}\right| \leq \lambda_{1}$.

Teorema 3. Jika dua entri yang berturutan $a_{i}$ dan $a_{i+1}$ dalam baris pertama dari sebuah matriks Leslie $L$ tidak sama dengan nol maka nilai eigen positif dari $L$ adalah dominan.

Disebut nilai eigen yang dominan jika $\left|\lambda_{k}\right|<\lambda_{1}$ tidak boleh $\left|\lambda_{k}\right|=\lambda_{1}$.

\section{Model Pemanenan Populasi Hewan (Harvesting of Animal Population Models)}

Dalam penelitian ini pemanenan (harvesting) adalah pengambilan hewan dari suatu populasi. Penelitian ini dibatasi dengan yang dinamakan kebijaksanaan pemanenan yang dapat dibenarkan (sustainable harvesting policies). Dalam penelitian yang dimaksudkan adalah sebagai berikut:

Definisi 1. Suatu kebijaksanaan pemanenan didalam mana suatu populasi hewan secara periodik dipanen dikatakan sebagai yang dapat dibenarkan jika hasil dari setiap panen adalah sama dan distribusi umur dari populasi yang masih tersisa setelah setiap panen adalah sama. Jadi populasi hewan itu tidak akan habis oleh kebijaksanaan pemanenan yang dapat dibenarkan hanya pertumbuhan yang lebih yang akan dimanfaatkan.

\section{Model Pemanenan}

Populasi domba betina mengalami periode pertumbuhan yang akan dijelaskan oleh matriks Leslie. Untuk menjelaskan model pemanenan ini secara matematis, misalkan

$$
\mathrm{x}=\left[\begin{array}{c}
x_{1} \\
x_{2} \\
\vdots \\
x_{n}
\end{array}\right]
$$

Adalah vektor distribusi umur dari populasi pada permulaan periode pertumbuhan tersebut. Jadi $x_{i}$ adalah banyaknya betina dalam kelompok ke- $i$ yang dibiarkan tak dipanen. Misalnya, jika populasi itu dipanen sekali setahun, maka populasi itu harus dibagi atas kelompok-kelompok umur satu tahun. Jika $L$ adalah matriks Leslie yang menjelaskan pertumbuhan populasi itu, maka vektor $L x$ adalah vektor distribusi umur dari populasi itu pada akhir periode pertumbuhan, segera sebelum panen 
periodik tersebut. Misalkan hi, untuk $i=1,2, \ldots, n$ adalah banyaknya bagian betina dari kelompok $i$ yang dipanen. Bilangan ke $n$ ini digunakan untuk membentuk matriks diagonal $n \times n$

$$
H=\left[\begin{array}{ccccc}
h_{1} & 0 & 0 & \cdots & 0 \\
0 & h_{2} & 0 & \cdots & 0 \\
0 & 0 & h_{3} & \cdots & 0 \\
\vdots & \vdots & \vdots & \ddots & \vdots \\
0 & 0 & 0 & \cdots & h_{n}
\end{array}\right]
$$

Yang dinamakan matriks pemanenan (harvesting matrix). Menurut definisi diperoleh $0 \leq h i \leq 1, \quad i=$ $1,2, \ldots, n$.

Jika tidak dapat memanen apapun $(h i=0)$ jika dapat memanen semuanya maka $(h i=1)$, jika dapat memanen sejumlah bagian tertentu $(0<h i<1)$ dari setiap kelompok dari ke-n kelompok tersebut. Karena banyaknya betina dalam kelas ke-i segera sebelum setiap panen adalah entri ke- $i$ dari vektor $L x$, yakni $(L x)_{i}$ maka dapat dilihat bahwa entri ke-i dari vektor kolom

$$
H L x=\left[\begin{array}{c}
h_{1}(L x)_{1} \\
h_{1}(L x)_{2} \\
\vdots \\
h_{1}(L x)_{n}
\end{array}\right]
$$

Adalah banyaknya betina yang dipanen dari kelompok ke-i. Dari definisi kebijaksanaan pemanenan yang dapat dibenarkan, maka diperoleh

$$
\left.\left[\begin{array}{c}
\text { distribusi umur } \\
\text { pada akhir } \\
\text { periode pertumbuhan }
\end{array}\right]-\text { panen }\right]=\left[\begin{array}{c}
\text { distribusi umur } \\
\text { pada permulaan } \\
\text { periode pertumbuhan }
\end{array}\right]
$$

Atau secara matematis,

$$
L x-H L x=x
$$

Persamaan (4) dapat ditulis dalam bentuk

$$
(1-H) L \mathbf{x}=\mathbf{x}
$$

Dapat dilihat bahwa $x$ harus merupakan sebuah vektor eigen dari matriks $(1-H) L$ yang bersesuaian dengan nilai eigen satu. Persamaan ini menempatkan kendala tersebut pada nilai hi dan nilai $\mathbf{x}$. Misalkan matriks Leslie dari populasi itu adalah

$$
L=\left[\begin{array}{cccccc}
a_{1} & a_{2} & a_{3} & \cdots & a_{n-1} & a_{n} \\
b_{1} & 0 & 0 & \cdots & 0 & 0 \\
0 & b_{2} & 0 & \cdots & 0 & 0 \\
\vdots & \vdots & \vdots & & \vdots & \vdots \\
0 & 0 & 0 & \cdots & b_{n-1} & 0
\end{array}\right]
$$




$$
(I-h) L=\left[\begin{array}{cccccc}
\left(1-h_{1}\right) a_{1} & \left(1-h_{1}\right) a_{2} & \left(1-h_{1}\right) a_{3} & \cdots & \left(1-h_{1}\right) a_{n-1} & \left(1-h_{1}\right) a_{n} \\
\left(1-h_{2}\right) b_{1} & 0 & 0 & \cdots & 0 & 0 \\
0 & \left(1-h_{3}\right) b_{2} & 0 & \cdots & 0 & 0 \\
\vdots & \vdots & \vdots & \cdots & \vdots & \vdots \\
0 & 0 & 0 & \cdots & \left(1-h_{n}\right) b_{n-1} & 0
\end{array}\right]
$$

Jadi $(1-h) L$ adalah matriks yang mempunyai bentuk yang sama seperti matriks Leslie. Syarat perlu dan cukup supaya matriks Leslie mempunyai nilai eigen sebesar satu adalah bahwa laju reproduksi netttonya adalah juga sebesar satu. Selanjutnya akan dihittung laju reproduksi nettonya dari $(1-h) L$. Nilai eigen dari $(1-h) L$ adalah akar-akar dari persamaan karakteristik

$r(\lambda)=0$.

$r(\lambda)=|\lambda I-(I-h) L|$

$$
r(\lambda)=\left[\begin{array}{ccccc}
\lambda I-\left(1-h_{1}\right) a_{1} & -\left(1-h_{1}\right) a_{2} & \cdots & -\left(1-h_{1}\right) a_{n-1} & -\left(1-h_{1}\right) a_{n} \\
-\left(1-h_{2}\right) b_{1} & \lambda & \cdots & 0 & 0 \\
0 & -\left(1-h_{3}\right) b_{2} & \cdots & 0 & 0 \\
\vdots & \vdots & \cdots & \vdots & \vdots \\
0 & 0 & \cdots & -\left(1-h_{n}\right) b_{n-1} & \lambda
\end{array}\right]
$$

Laju reproduksi netto dari $(I-h) L$ adalah

$\left(1-h_{1}\right)\left[a_{1}+a_{2} b_{1}\left(1-h_{2}\right)+a_{3} b_{1} b_{2}\left(1-h_{2}\right)\left(1-h_{3}\right)+\cdots+a_{n} b_{1} b_{2} \cdots \quad b_{n-1}\left(1-h_{2}\right) \cdots\left(1-h_{n}\right)\right]=1$

Persamaan (6) menempatkan sebuah kendala pada banyaknya bagian pemanenan yang diperbolehkan, dimana hanya nilai-nilai $h_{1}, h_{2}, \ldots . h_{n}$ yang memenuhi persamaan (6) dan terletak dalam interval $[0,1]$ yang dapat menghasilkan hasil yang dapat dibenarkan, jika $h_{1}, h_{2}, \ldots . h_{n}$ memenuhi persamaan (6) maka matriks $(I-h) L$ akan mempunyai nilai eigen $\lambda_{1}=1$. Karena $\lambda_{1}=1$ maka

$$
x_{1}=\left[\begin{array}{c}
1 \\
b_{1}\left(1-h_{2}\right) \\
b_{1} b_{2}\left(1-h_{2}\right)\left(1-h_{3}\right) \\
\vdots \\
b_{1} b_{2} \ldots b_{n-1}\left(1-h_{2}\right)\left(1-h_{3}\right) \ldots\left(1-h_{n}\right)
\end{array}\right]
$$

Vektor $x_{i}$ akan menentukan peluang betina yang dibiarkan atau tidak dipanen dalam suatu pemanenan.

\section{Pemanenan Yang Merata (Uniform Harvesting)}

Dengan banyaknya populasi maka akan sukar membedakan mana yang umurnya spesifik. Jika hewan dipanen secara acak, maka secara acak dapat dianggap bahwa banyaknya bagian yang sama dari setiap kelompok umur telah dipanen. Oleh karena itu ditetapkan bahwa $h=h_{1}=h_{2}=\cdots=h_{n}$. Akan direduksi persamaan $(1-h) L \mathbf{x}=\mathbf{x}$. Karena $h=h_{1}$ maka $L \mathbf{x}=\left(\frac{1}{1-h}\right) \mathbf{x}$. Jadi $\frac{1}{1-h}$ harus merupakan nilai eigen positif $\lambda_{1}$ yang tunggal dari matriks pertumbuhan Leslie $L$ tersebut yaitu $\lambda_{1}=\frac{1}{1-h}$. Selanjutnya akan diselesaikan untuk mendapatlan peluang pemanenan $h$

$$
\left(1-h_{1}\right) \lambda_{1}=1 \text { sehingga } h=1-\frac{1}{\lambda_{1}}
$$

Vektor $x_{1}$ adalah sama seperti vektor eigen dari $L$ yang bersesuaian dengan nilai eigen $\lambda_{1}$. 


$$
x_{1}=\left[\begin{array}{c}
1 \\
b_{1} / \lambda_{1} \\
b_{1} b_{2} / \lambda_{1}^{2} \\
\vdots \\
b_{1} b_{2} \ldots b_{n-1} / \lambda_{1}^{n-1}
\end{array}\right]
$$

Berikut ini adalah contoh periode pertumbuhan domba disuatu daerah dengan periode pertumbuhan selama 1 tahun per 1000 kelahiran domba. $a_{i}$ menunjukkan angka kesuburan dan bi menunjukkan angka harapan hidup domba betina selama 1 tahun. Domba ini mempunyai umur maksimal 12 tahun sehingga populasinya terbagi atas 12 kelompok umur.

Tabel 2. Angka Kesuburan Dan Harapan Hidup Populasi Domba Betina.

\begin{tabular}{ccc}
\hline $\boldsymbol{I}$ & $\boldsymbol{a}_{\boldsymbol{i}}$ & $\boldsymbol{b}_{\boldsymbol{i}}$ \\
\hline $0-1$ & 0,000 & 0,846 \\
$1-2$ & 0,046 & 0,976 \\
$2-3$ & 0,392 & 0,966 \\
$3-4$ & 0,473 & 0,951 \\
$4-5$ & 0,485 & 0,927 \\
$5-6$ & 0,547 & 0,896 \\
$6-7$ & 0,544 & 0,851 \\
$7-8$ & 0,503 & 0,787 \\
$8-9$ & 0,469 & 0,692 \\
$9-10$ & 0,460 & 0,562 \\
$10-11$ & 0,434 & 0,371 \\
$11-12$ & 0,422 & ------ \\
\hline
\end{tabular}

Matriks Leslie untuk Tabel 2. di atas adalah

$$
L=\left[\begin{array}{cccccccccccc}
0.000 & 0.046 & 0.392 & 0.473 & 0,485 & 0.547 & 0.544 & 0.503 & 0.469 & 0.460 & 0.434 & 0.422 \\
0.846 & 0 & 0 & 0 & 0 & 0 & 0 & 0 & 0 & 0 & 0 & 0 \\
0 & 0.976 & 0 & 0 & 0 & 0 & 0 & 0 & 0 & 0 & 0 & 0 \\
0 & 0 & 0.966 & 0 & 0 & 0 & 0 & 0 & 0 & 0 & 0 & 0 \\
0 & 0 & 0 & 0.951 & 0 & 0 & 0 & 0 & 0 & 0 & 0 & 0 \\
0 & 0 & 0 & 0 & 0.927 & 0 & 0 & 0 & 0 & 0 & 0 & 0 \\
0 & 0 & 0 & 0 & 0 & 0.896 & 0 & 0 & 0 & 0 & 0 & 0 \\
0 & 0 & 0 & 0 & 0 & 0 & 0.851 & 0 & 0 & 0 & 0 & 0 \\
0 & 0 & 0 & 0 & 0 & 0 & 0 & 0.787 & 0 & 0 & 0 & 0 \\
0 & 0 & 0 & 0 & 0 & 0 & 0 & 0 & 0.692 & 0 & 0 & 0 \\
0 & 0 & 0 & 0 & 0 & 0 & 0 & 0 & 0 & 0.562 & 0 & 0 \\
0 & 0 & 0 & 0 & 0 & 0 & 0 & 0 & 0 & 0 & 0.371 & 0
\end{array}\right]
$$

Dari perhitungan menggunakan MAPLE diperoleh Nilai eigen positif dari matriks Leslie yang tunggal, yaitu $\lambda_{1}=1,177$.

Berdasarkan persamaan yaitu $h=1-\frac{1}{\lambda_{1}}$, maka banyaknya bagian pemanenan $h$ adalah $h=1-\left(\frac{1}{\lambda_{1}}\right)=1-\left(\frac{1}{1,177}\right)=0,150$. Berdasarkan perhitungan dengan MAPLE diperoleh 


$$
\mathbf{x}_{1}=\left[\begin{array}{c}
1 \\
0,719 \\
0,596 \\
0,489 \\
0,395 \\
0,311 \\
0,237 \\
0,171 \\
0,114 \\
0,067 \\
0,032 \\
0,010
\end{array}\right], \quad L \mathbf{x}_{1}=\left[\begin{array}{c}
1,177 \\
0,846 \\
0,701 \\
0,576 \\
0,465 \\
0,366 \\
0,279 \\
0,201 \\
0,135 \\
0,079 \\
0,038 \\
0,012
\end{array}\right], \quad h L \mathbf{x}_{1}=\left[\begin{array}{l}
1,177 \\
0,127 \\
0,105 \\
0,087 \\
0,070 \\
0,055 \\
0,042 \\
0,030 \\
0,020 \\
0,012 \\
0,006 \\
0,002
\end{array}\right]
$$

Jadi kebijaksanaan pemanenan yang merata adalah kebijaksanaan dimana 15\% dari domba setiap kelompok dalam ke-12 kelompok umur tersebut dipanen tiap tahun. Dari $h L x 1$ dapat ditentukan bahwa untuk 1000 domba kelompok umur antara 0 dan 1 tahun dipanen sebanyak 177 ekor dan untuk domba kelompok umur antara 1 dan 2 tahun dipanen sebanyak 127 ekor, domba kelompok umur antara 2 dan 3 tahun dipanen sebanyak 105 ekor dan seterusnya. Sehingga secara keseluruhan domba yang dipanen adalah 733 ekor.

\section{Pemanenan Kelompok Umur Yang Termuda}

Dalam beberapa populasi, hanya populasi betina termuda saja yang mempunyai nilai ekonomis, sehingga pemanen hanya ingin memanen betina dari kelompok umur yang termuda. Berdasarkan hal tersebut maka $h_{1}=h ; h_{2}=h_{3}=\cdots=h_{n}=0$. Persamaan (6) direduksi menjadi

atau

$$
(1-h)\left(a_{1}+a_{2} b_{1}+a_{3} b_{1} b_{2}+. .+a_{n} b_{1} b_{2} . . b_{n-1}\right)=1
$$

$$
(1-h) R=1
$$

Diana $R$ adalah laju reproduksi netto dari populasi tersebut. Dengan memecahkannya untuk $h$ diperoleh

$$
h=1-\left(\frac{1}{R}\right)
$$

Dari persamaan (7) kita perhatikan bahwa kebijaksanaan pemanen yang dapat dibernarkan akan mungkin hanya jika $R>1$. Hal ini adalah wajar karena populasi itu akan bertambah hanya jika $R>$ 1. Dari persamaan

$$
x_{1}=\left[\begin{array}{c}
1 \\
b_{1}\left(1-h_{2}\right) \\
b_{1} b_{2}\left(1-h_{2}\right)\left(1-h_{3}\right) \\
\vdots \\
b_{1} b_{2} \ldots b_{n-1}\left(1-h_{2}\right)\left(1-h_{3}\right) \ldots\left(1-h_{n}\right)
\end{array}\right]
$$

Vektor distribusi umur setelah setiap panen adalah vektor

$$
x_{1}=\left[\begin{array}{c}
1 \\
b_{1} \\
b_{1} b_{2} \\
\vdots \\
b_{1} b_{2} \ldots b_{n-1}
\end{array}\right]
$$




\section{Contoh}

Marilah kita terapkan jenis kebijaksanaan yang dapat dibenarkan ini kepada populasi domba berdasarkan dalam tabel 5.3 yaitu pertumbuhan populasi domba selama 1 tahun. Untuk laju reproduksi netto dari populasi tersebut, kita dapatkan:

$R=a_{1}+a_{2} b_{1}+a_{3} b_{1} b_{2}++a_{n} b_{1} b_{2} \ldots b_{n-1}$

$R=2,533944242$ (dibulatkan 2,534)

Dari persamaan (5.22), maka peluang kelompok umur pertama yang dipanen adalah

$h=1-\left(\frac{1}{R}\right)=1-\left(\frac{1}{2,534}\right)=0.605$

Dari persamaan (5.23), maka distribusi umur dari populasi domba itu setelah panen adalah sebanding dengan vektor.

$$
\mathbf{x}_{1}=\left[\begin{array}{c}
1 \\
0,846 \\
0,826 \\
0,798 \\
0,759 \\
0,703 \\
0,630 \\
0,536 \\
0,422 \\
0,292 \\
0,164 \\
0,061
\end{array}\right], \text { vektor } L \mathbf{x}_{1}=\left[\begin{array}{c}
2,534 \\
0,846 \\
0,826 \\
0,798 \\
0,759 \\
0,703 \\
0,630 \\
0,536 \\
0,422 \\
0,292 \\
0,164 \\
0,061
\end{array}\right]
$$

Vektor $L \mathbf{x}_{1}$ Adalah vektor distribusi umur segera sebelum panen.

Jumlah seluruh entri dalam $L \mathbf{x}_{1}=8,571$, sehingga entri pertama, yakni 2,534 adalah $29.6 \%$ dari jumlah seluruh entri $L \mathbf{x}_{1}$ tersebut. Hal ini dapat diartikan bahwa segera sebelum setiap panen 29,6\% dari populasinya berada dalam kelompok umur yang termuda. Sehingga keseluruhan populasi domba yang dipanen setiap tahun adalah sebesar $17,9 \%$ (=60,5\% dari $29,6 \%)$. Jadi, kebijaksanaan pemanenan kelompok umur yang termuda adalah $17,9 \%$ dari seluruh populasi domba dipanen atau untuk 1000 domba dipanen 179 ekor setiap tahunnya.

\section{Kesimpulan}

Berdasarkan pembahasan yang telah diuraikan sebelumnya maka dapat disimpulkan beberapa hal yaitu nilai eigen positif pada matriks Leslie dengan pemanenan berdasarkan perhitungan aplikasi MAPLE adalah sebesar $\lambda_{1}=1,177$. Vektor eigen pada matriks Leslie dengan pemanenan pada kelompok umur termuda (Harvestingthe youngest class) adalah sebesar 


$$
\mathbf{x}_{1}=\left[\begin{array}{c}
1 \\
0,846 \\
0,826 \\
0,798 \\
0,759 \\
0,703 \\
0,630 \\
0,536 \\
0,422 \\
0,292 \\
0,164 \\
0,061
\end{array}\right]
$$

Kebijaksanaan pemanenan dari masing-masing kelompok umur populasi domba betina saat pemanenan tiap tahun adalah sebesar $17,9 \%$. Jadi, kebijaksanaan pemanenan kelompok umur yang termuda adalah sebesar 17,9\% yaitu 179 ekor setiap tahun dari 1000 populasi domba betina.

\section{Referensi}

Buku:

[1] Anton, H. \& Rorres, C. 1988. Penerapan Aljabar Linear. Jakarta: Erlangga.

[2] Anton, H. \& Rorres, C. 2004. Aljabar Linear Elementer (versi Aplikasi). Jakarta: Erlangga.

[3] Emlen, J.Merriit. 1973. Ecology An Evolutionary Approach. New York: Addison-Wesley Publishing Company, Inc.

[4] Kariadinata, Rahayu. 2013. Aljabar Matriks Elementer. Bandung: CV PustakaSetia.

[5] Moleong, L. 2014. Metodologi Penelitian Kualitatif. Edisi Revisi. Bandung: PT Remaja Rosdakarya.

[6] Sugiyono. 2011. Metode Penelitian Kualitatif, Kuantitatif, dan R\&D, Bandung: Alfabeta.

Jurnal:

[7] Corazon, C.M, Nurul, H \& Yusienta, M. 2016. Aplikasi Matriks Leslie Untuk Memprediksi Jumlah Dan Laju Pertumbuhan Perempuan Di Provinsi Riau Pada Tahun 2017. Jurnal Sains Matematika dan Statistika (JSMS), 2 (3),111.

[8] Lestari, Dwi. 2009. Penerapan Diagonalisasi Matriks Dan Matriks Leslie Dalam Memproyeksikan Jumlah Populasi Perempuan, Pythagoras, 5(1), 45-53.

[9] Yuliani, S., Rahayu \& Mashuri., Penerapan Diagonalisasi Matriks Dan Matriks LeslieDalam Memproyeksikan Jumlah Populasi Perempuan, Unnes Journal of Mathematich (UJM), 1(1), 62-70.

[10] Pratama, Yudi, dkk. 2013. Aplikasi Matriks Leslie Untuk Memprediksi Jumlah Dan Laju Pertumbuhan Suatu Populasi. Bimaster: Buletin IImiah Math. Stat. Dan Terapannya, 2(3), 163-172. 